\title{
Conjugal Love from a Sociological Perspective: Theorizing from Observed Practices.
}

\author{
Helene Belleau \\ Chiara Piazzesi \\ AnNabelle SEery
}

\begin{abstract}
This paper presents a sociological reflection on contemporary conjugal love, both from an empirical and a theoretical point of view. Drawing on analyses of data regarding financial arrangements between partners forming a couple, as well as on the sociological literature concerning love relationships, we present a theorization of contemporary conjugal semantics. We define these semantics as consisting of eight "meaning rules" through which social actors respond to the challenges of intimate relationships. Our analysis shows us the gaps and the tensions between different logics of love, on the one hand, and logics of love and social realities, on the other. However, partners' utterances feature an integration of elements stemming from opposed semantic frameworks; meaning rules fostering mythical idealisation are combined with rules regarding relationship work, therapeutic communication, and the entrepreneurial management of the relationship. This empirical analysis also allows us to tackle a double confusion in the contemporary sociological literature on love and couples.
\end{abstract}

Keywords: Love; marriage relationships; semantics; sociology; practices.

Résumé. Cet article propose une réflexion sociologique sur l'amour conjugal contemporain d'un point de vue théorique et empirique. À partir de données recueillies sur les arrangements financiers de personnes vivant en couple et de la littérature sociologique sur l'amour, les auteures dégagent une sémantique de la conjugalité contemporaine illustrée par huit « règles de sens », mobilisées par les acteurs pour répondre aux défis des relations intimes. L'analyse permet d'observer les décalages entre différentes logiques amoureuses d'une part, et de l'autre entre les logiques de l'amour et les réalités sociales. Les propos des conjoints révèlent l'intégration d'éléments qui tiennent de logiques divergentes dans un même univers de sens : des règles de sens favorisant l'idéalisation mythique conjuguées à celles organisées autour des images du travail sur la relation, de la communication thérapeutique et de la prise en charge entrepreneuriale de 
la relation. Cette analyse empirique conduit les auteures à cerner une double confusion dans la littérature contemporaine sur l'amour et les couples.

Mots clés: Amour ; relations conjugales ; sémantique ; sociologie ; pratiques

\section{INTRODUCTION}

2ociological literature on love in Western societies has investigated the love imaginaries governing the experiences and behavior of partners in intimate relationships. This article extends this line of inquiry by defining the dominant semantics of love in contemporary Western societies. It aims at tackling the main semantic patterns on the basis of which partners construct a stable long-term heterosexual conjugality, be it marriage or an equivalent reciprocal commitment, through their practices, thoughts, and utterances. "Semantics" refers to an organized, structured, and historically constituted repertoire of meaning rules (Luhmann 1997, 1982). Social actors are not necessarily aware of the meaning rules they themselves employ, which may remain implicit (sometimes even for sociologists; see Jackson 1993), often embedded in stories or proverbs. These meaning rules are rather an abstraction formulated by scholars, firstly through observation of regularities in people's discourse and behavior, and then on the basis of socially available representations of intimacy (for instance, in media and cultural productions).

In addition to this first level of theorization, our analysis allows us to observe discrepancies between opposite or contradictory meaning rules, on the one hand, and between love meaning rules and social realities (such as high divorce rates, serial monogamy, gender inequalities in the division of labor and separations) on the other.

Our interviews with couples document the coexistence and even the integration of meaning rules stemming from mythical idealization of love with meaning rules stemming from an entrepreneurial conception of love relationships. Partners can act and speak as though their love were endless, putting an emphasis on the idea of destiny (as opposed to the idea of choice) in selecting their partner, and feel compelled to act selflessly in their conjugal interaction. However, at the same time, partners can combine this traditional conception of love with a more modern injunction to relationship work, rational choice action, communication as therapy, and so on. Seemingly contradictory logics contribute jointly to the effort of stabilizing an intimate relationship. The earmarking of money within couples reveals the tensions between different semantic references. More 
specifically, our observations show that the traditional semantics of romantic love are sometimes mobilized to motivate and justify actions that deviate from an economic model of rationality.

We have analyzed interview data collected from heterosexual couples in Quebec. Participants were asked questions concerning the arrangements and practices through which they managed their partnerships, including financial arrangements. Individual interviews were carried out across the course of four research projects conducted in Quebec between 2005 and 2012. These projects produced 160 qualitative interviews, averaging 2 hours. Every interview featured a series of open questions concerning the economic arrangements between spouses and participants' expectations and attitudes towards marital life. Through a variety of techniques (word of mouth, community organizations, etc.) 20 interviewers (17 women and 3 men) recruited a group of participants aged between 22 and 62 years, each of whom was living as a couple. Interviews were held mainly in large urban centers (Montreal, Quebec City, Trois-Rivières) and suburbs, but also in more rural areas of Quebec (Montérégie, Laurentides, Lanaudière, and Bas-St-Laurent).

In order to provide different perspectives on intimate relationships and practical arrangements, the following variables were taken into account in the four research projects sex; marital status (half of the participants consulted were married spouses, while the other half were de facto partners); parental status (with or without children); socio-economic status through education (secondary, college and university diploma); and sometimes place of residence. Spouses in de facto unions were required to have three years of cohabitation or to have a child to compare couples with a similar life path (VilleneuveGokalp 1990). With about 30 of the couples, both spouses were interviewed separately. However, no couple interview was carried out. All interviews were transcribed and coded in their entirety.

The secondary analysis that we present in this paper has a number of limitations. For instance, since the sample only includes individuals living in a couple, the point of view of individuals who are not living in a relationship is not represented in our analysis. With the exception of gender, the different variables taken into account in the sample (age, education, parental status, etc.) did not allow differences to emerge during analysis. This is likely another limitation of our study.

We will begin with a definition of the semantics of love, and then move to a discussion of the existing sociological literature. We will then present the eight "meaning rules" that have emerged from our data. Drawing on our analyses, we will conclude by discussing 
some confusions prevalent in the scholarly literature which can be dispelled by performing empirical research.

\section{Love Semantics}

Love semantics is a structured set of meaning rules. These rules form a coherent repertoire of symbols, images and narratives that define places, moments, identities, roles, discourses, and behaviors related to love (for instance, paying the bill at a restaurant, looking one's partner in the eyes, holding a partner's hand, kissing on the mouth, "self-sacrificing," writing a love letter, moving in together, etc.). This repertoire is historically constituted and is subject to historical change. A system of meaningful connections between semantic elements is partially crystallized by repetition and organized in meaning rules that allow us to identify and experience "love" (Luhmann 1997: 76). At the same time, this system of interpretation is constantly evolving as a result of discourses and social practices and, more specifically, of mediated communication. Love semantics is socially transmitted mainly through different cultural products (proverbs, sayings, stories, novels, TV shows, movies, paintings, etc.) and mass media (Luhmann 1982; Evans 2003; Reinhardt-Becker 2015; Raghu 2015). The meaning rules that structure love semantics preselect the range of possible (contextual) interpretations of a gesture, expression, word, or utterance in a given situation. Hence, these rules define and stabilize legitimate expectations with regard to the behavior of oneself and others. By operating on a shared and generalized basis, these rules allow mutual understanding within interactions, which in turn facilitates the constitution of relationships. Moreover, as we will show, these meaning rules refer to each other, forming a consistent repertoire.

We have identified eight meaning rules that operate in long-term conjugality (as opposed to ephemeral relationships or to "falling in love"): 1) the fiction of duration; 2) love as destiny, or the involuntary nature of love; 3) love as work, or the ongoing investment in the relationship; 4) the imperative of communication; 5) self-sacrifice and disinterest; 6) delayed reciprocity; 7) trust and 8) fidelity. Organized around these rules, love semantics function as a repertoire of generalized and socially accessible "scripts" (Simon and Gagnon 2002), which are adapted and recreated by actors in concrete intimate situations, i.e. when "love" is the case. By using love semantics, people weave the fabric of their own "love stories" (Averill and Boothroyd 1977, Jackson 2003, Kauffman 2002). The indeterminate temporality 
and the exemplary character of semantic elements, which are drawn from stories, proverbs, tales, novels, and traditional metaphors, makes them immediately available for a paradigmatic use (Ricoeur 1984); these elements function as meaning rules that direct actors in interpreting the situations of ordinary life, in their reactions to these situations, and in the organization of their legitimate expectations with respect to others' behavior.

Luhmann (1982) and other scholars (Tyrell 1987; Rougemont 1972) have reconstructed the historical evolution of Western love semantics and its different stages, ranging from love as passion $\left(16^{\text {th }}\right.$ to $17^{\text {th }}$ century) to romantic love ( $18^{\text {th }}$ to $19^{\text {th }}$ century) and love as partnership ( $20^{\text {th }}$ to $21^{\text {st }}$ century). At different stages of this semantic evolution, different themes emerge which replace those that dominated the previous stage. However, these themes are not necessarily new and original, rather are often a reorganization of already existing topics. For example, the idea of love as destiny, and the corresponding understanding of love as involuntary were already present in Plato's dialogues, and were further developed by courtly and passionate love. This theme also appears in more modern forms of intimate and conjugal relationships, which are hinged on partnership semantics.

The evolution of love semantics follows a different temporality from societal evolution; for this reason, love semantics can test innovations that are not yet integrated into practices and social structures. They can also preserve old-fashioned, traditional ideas and concepts, thus "hiding" social change (Luhmann 1993: 7). For example, despite the fact that all respondents are aware of the high rate of break-ups and separations, the fiction of duration still is a fundamental meaning rule. Such rule contributes to «hide» this social reality and leads partners to disregard the possibility of divorce or separation. Another example concerns egalitarian norms characterizing discourses and practices of contemporary couples. Although spouses tend to endorse equality, the meaning rule of "self-sacrifice and disinterest" discourages spouses to address inequalities even when they are aware of them (Coontz 2016). In addition, this meaning rule leads partners to take for granted that their spouse will not prioritize his or her interests over the partner's (Henchoz 2014: 32). Therefore, love semantics must not be confused with detailed descriptions of the reality of practices and discourses. The relative absence of an empirical basis in some sociological theories of intimate life, including for example Giddens' (1992), results in confusion when such theories appear to describe practices despite describing only the dominant imaginaries of love (Jamieson 1999 ; Piazzesi 2014). To avoid this difficulty, our theorization instead begins with a 
consideration of an empirical data set, and carefully generalizes the emerging discursive and practical patterns, organizing them on the basis of the above-mentioned meaning rules.

\section{Contemporary Love Semantics of Love within a Conjugal Context}

It is possible to identify three main stances (van Hoof 2013) in the sociological literature depicting romantic imaginaries in contemporary Western societies. The first stance is the thesis that equates detraditionalization with emancipation. According to Beck and Beck-Gernsheim (2001, 1995), a progressive liberation from traditional normative references has "individualized" love; today, the individuals composing couples and families are able to negotiate their own normative references. As an effect of this negotiability, normative references are increasingly more changeable, customizable, and temporary. In The Transformation of Intimacy (1992), Giddens argues that the romantic love pattern has been replaced by a "pure relationship," in which two independent and equal partners engage in a relationship for as long as it contributes to the personal self-fulfillment of each. The popularity of Giddens's thesis in the scientific literature can be attributed to the fact that it seems to reflect the modern normative ideal (Piazzesi 2014), as well as cohering with the theoretical positions of sociologists who describe contemporary societies as "liquid" (Bauman 2004). The "disappearance" (Théry 1993) or "deinstitutionalization" (Cherlin 2004, Coontz 2005) of marriage has been accompanied by a multiplication of socially acceptable forms of conjugality. This diversification seems to corroborate Giddens' (1992) and Bauman's (2004) thesis concerning the de-solidification of intimate ties. Other phenomena such as polyamory and forms of non-conjugal or more ephemeral relationships ${ }^{1}$ appear to point in the same direction.

The second stance, which is fundamentally consistent with the first, depicts modernization as the dissolution of bonds and forms of reciprocal commitment that once made love possible and compatible with conjugality. "Colonized" (Musiał 2013) by the logic of economic rationality, by neoliberal capitalism (Illouz 1997, 2012), and by consumer culture, love has lost the durability of its connective power and increasingly expresses itself only in ephemeral and fragile relationships. Adherents to this stance interpret the regression of conjugal institutions

1. On the boundaries of monogamy, see Frank and DeLamater (2010). 
and lasting intimate bonds as the "end of love" (Hillenkamp 2009). The dominant intimate semantics, which are still mainly romantic, are considered to be fatally "corrupted" by neoliberal consumer culture and individualization.

While theoretically interesting, few of the works elaborating this stance are based on empirical evidence. Advocates of a thirds stance, who are represented in a variety of disciplines, have criticized theorists adhering to the first two stances for failing to take into account the inertial force exerted by persistent traditional values, roles, and patterns of intimacy. Additionally, theorists of modernization have not adequately taken into account factors which continue to reduce "freedom" and hinder equality, such as material limitations, the duties and responsibilities of spouses, and the presence of children (Cherlin 2004; Jamieson 1999). Like other researchers such as Roussel (1989), Gross (2005), Cherlin (2004), Popenoe and Whitehead (2001), and on the basis of our empirical studies, we observe a persistence of normative elements in contemporary Western love semantics. Despite the diversification of socially accepted intimate ties and the presence of more and less "serious" commitments in a life course, traditional normative references continue to linger (Giraud 2017). Notwithstanding current and past transformations, the traditional love imaginary still plays a major role in Western social relations and intimate bonds. Traditional semantics are transmitted by literature, movies, TV shows, and more generally by mass media (Dowd and Pallotta 2000, Hefner and Wilson 2013, Reinhardt-Becker 2015). They are also endorsed by counselors and specialists (religious and spiritual guides, therapists, psychologists, sexologists, journalists, etc.) who inform the members of a society of the rights, responsibilities and, more generally, the principles and expectations that should guide them (Jackson 2014, Blais et al., 2014). Despite the increasing diversification and precarity of social ties, some semantic patterns nevertheless remain central, combining with more modern entrepreneurial and therapeutic patterns (Jonas 2007), and with different forms of romantic idealization.

\section{Love AND ITs "Meaning Rules"}

In this section, we document and discuss the coexistence of traditional and non-traditional patterns in contemporary Western love semantics. In this discussion, we present the eight main "meaning rules" that have emerged from our data, additionally highlighting the tensions between imaginaries of romantic and modern love. 


\section{The fiction of duration}

Despite the fact that the frequency of break-ups, separation and divorce constantly reminds us of the fragility of intimate bonds, contemporary couples still think and act as if their love relationship were endless. The fiction of duration still is a fundamental meaning rule that orients behaviors and interpretations related to love. As long as this fiction does not conflict with empirical evidence and reality tests, the relationship is considered to be stable and everlasting. This meaning rule represents the legacy of a long discursive tradition, according to which love's authenticity is to be assessed on the basis of its ability to last; in this tradition, the stability of true love cannot be shaken by individual, temporal, or social change (Luhmann 1982).

The fiction of duration creates a blind spot in the couple relationship, which leads to a form of obliviousness observed in discourses as well as in conjugal practices (Baker and Emery 1993, Bowman 2010, Williams 2009); very few spouses anticipate the effects, problems and difficulties that arise in the event of a breakup. Drawing on our research as well as other scholars' on the way couples manage money, we claim that this rule of meaning, combined with others (delayed reciprocity, self-sacrifice and disinterest, trust), sometimes limits individual demands, but also legal and financial «negotiations» between spouses. Several scholars have highlighted conflicting attitudes within couples, that often go unaddressed by the partners. Also, research has shown important gaps between egalitarian claims and more traditional practices and arrangements, as well as the effects of such gaps (Jamieson et al, 2002; Nyman, 1999; Pahl, 2005). The difficulty of questioning the fiction of duration can be explained by the synergy between this meaning rule and a double psychological bias. The first bias, the "above average effect," leads one to consider oneself less likely than most people to experience a negative event, be it an accident, an illness, a divorce, or a separation (Gigerenzer 1991, Higgins et al. 1997, Rachlinski 2003). The second, the "optimism" bias, plays a central role in the process of building a conjugal life. This bias works as a self-fulfilling prophecy (Armor and Taylor 1998, Reece 2015, Sharot 2012); partners are disproportionately optimistic about the prospects of their relationship, and feel protected from a possible break-up. As a result of this bias, they incessantly invest in their relationships, which in turn solidifies the relationship itself. Conversely, anticipating the end of a relationship makes partners more likely to disengage, and can accelerate a break-up. Optimism bias is also observed when partners are led to imagine the possibility 
of a breakup; many remain convinced that their love will be strong enough to ensure an amicable and mature separation process (Belleau, 2011). The quality of their current relationship, the number of years they have spent together, and their mutual trust are taken as evidence that partners would conduct their separation amicably. This attitude is illustrated very well by the utterance of a participant who contended that "I would do it in the fairest and most generous way possible if we ever separate, because it's still someone I love, that I respect, with whom I wanted to have children [...] I think it would be an amicable agreement anyway" (Jacques, male participant, de facto union).

The fiction of duration is also observed in partners' disinclination to make concrete legal or financial arrangements to deal with the material consequences of a break-up; most partners actually behave as if their relationship will last forever.

\section{Love as destiny, or the involuntary nature of love}

This meaning rule states that love does not depend on a conscious decision or on rational action (Chaumier 1999, Henchoz 2008). That we "fall in love" as we have an accident is highlighted by the images and metaphors frequently used to narrate the beginnings of romantic relationships (Lemieux 2003, Schurmans and Dominicé 1997): "destiny," "love at first sight," "chance," "coup de foudre," and even "soul mate" suggest that a loved one is not chosen, but rather that he or she was destined for us, as the only one possible ${ }^{2}$ (Bergström 2013, Bozon and Héran 1987, Jackson 1993) ${ }^{3}$.

When coupled with the fiction of duration, the idea of love as destiny makes the involuntary ending of a relationship, for instance the death of one's partner, much more acceptable than a voluntary separation. This is illustrated by the fact that many of the de facto partners who we interviewed were more likely to write a will than a cohabitation

2. Swidler (2001: 26) emphasizes the coexistence, among her middle class, American participants, of two seemingly contradictory love semantics: according to the first, love is a voluntary commitment; according to the second, to love someone is not a personal decision. In our sample, we observed the second semantics, although interviewees also mentioned love as work and continuous investment in the relationship. These combined rules of meaning, while contradictory, can coexist.

3. This is a commonplace that studies on homogamy partially contradict. Homogamy refers to the fact that people tend to choose a partner in the social group (occupation, cultural background, socio-economic status, level of education etc.) to which they belong. 
agreement ${ }^{4}$, since in doing the latter, one would have to entertain the inadmissible thought that partners could willingly decide to terminate their relationship (Belleau, 2011). In contrast, a will is seen as an altruistic gesture, an act of taking care of the other even after death. When asked directly, very few partners conceded having planned arrangements in the event of a break-up (in the form of savings, financial agreements, etc.). Much like the fiction of duration, the idea of love as destiny relegates the social phenomenon of conjugal instability to a blind spot.

\section{Love as work, or the ongoing investment in the relationship}

A third meaning rule defines the intimate relationship as the result of ongoing work. Love is built through daily, sustained investment in the relationships, as well as through renewed mutual demonstrations of commitment (Kruithof 1979; Mahlmann 1991; Luhmann 1982). Such commitment requires conscious and consistent efforts to maintain harmony, communication, transparency and trust. While one falls in love without having decided it, the subsequent commitment rests on the reiteration of the will to live together (Swidler 2001).

With the emerging romantic paradigm of the $19^{\text {th }}$ century, the idea that people can "work" on their relationship was already circulating. This relationship work, which $19^{\text {th }}$ century self-help books already identify as women's prerogative (Mahlmann 1991), is regarded as a sign of the good intentions and commitment of spouses to their love and marriage. The implicit idea is that, if done correctly, there is no intrinsic reason for love to fail. And in the event that a love does fail, the blame is attributed to a neglectful spouses. Jonas's research (2007) shows the persisting gendered imbalance of this "relational work"; even late $20^{\text {th }}$ century counseling literature still encourages women to be the "managers" of their couple as a sign of love.

In Quebec, the injunction to ongoing investment in one's relationship has ironically undermined the very institution of marriage in which it was once expressed. The promise of reciprocal engagement as an official act that occurs at a specific time once and for all, is now perceived as being at odds with the idea of ongoing investment in a relationship (Bozon 2016) ${ }^{5}$. Because the legal framework surrounding marriage in

4. In Quebec, de facto spouses have the opportunity to sign an agreement between them which allows for the definition of the obligations of each partner during the relationship and to predict, for example, what will become of property and children in case of separation.

5. Today in Quebec $40 \%$ of couples live outside marriage, which represents the largest proportion of de facto partners in Canada (Statistics Canada, 2017). In 2006, Quebec was also leading the way in most countries for which recent 
Quebec allows more or less formal celebrations, these events sometimes resemble love rituals (marriage celebrated at home, in privacy, in bucolic places, etc.) more than public statements of a lifelong commitment. Several participants explained that they married to celebrate ten, fifteen or twenty years together, as the literature also points out (Girard et al., 2013). In such arrangements, marriage is understood as another way to maintain and revive the passion in a relationship (Maillochon 2016). A female participant, Maryse, who has been married for one year following two decades of cohabitation, expressed this idea in terms of daily commitment: "I think you can be as committed, in a de facto relationship, depending on your beliefs, simply. [...] We have been happy for 20 years. Daily commitment was present before as after marriage." For many couples, having children together involves a greater commitment than marriage itself precisely because it corresponds to the idea of a common daily investment in their relationship (Belleau 2011).

\section{Communication}

The idea of relationship work is closely related to the injunction to communicate; by expressing themselves in a conjugal dialogue, partners show their ongoing investment in their relationships (Martin 2003; Treas et al 2014). This injunction is a central aspect of the $20^{\text {th }}$ century semantics of love as partnership, and is the result of the merging of therapeutic and democratic cultures in intimate relationships (Giddens 1992; Jamieson 1999) with the "emotional" turn of capitalism in the $20^{\text {th }}$ century (Illouz 1997).

Among our participants, communication was often seen as an important bulwark that helps to maintain togetherness and avoid the threat of a break-up. For example, one woman identified communication as one of the three key features of a love relationship: "Communication, for me, that's the secret, if you do not want conflicts that can escalate and become unbearable and just break a couple" (Anne, female participant, de facto union). This meaning rule also implies a rejection of legal arrangements and solutions; legal action (writing or breaking a contract) is often perceived as an admission that a conflict cannot be overcome through communication, or that there is an absence of communication. Conversely, the avoidance of legal counseling while separating is seen as a sign of maturity, trust, and productive dialogue (Volery 2011).

data are available, including Sweden (25.4\%) and Finland (23, $9 \%$ ) (Milan et al., 2007). The majority of children are born from unmarried parents in Quebec (Girard et al., 2012). 


\section{Altruism and disinterest}

A well-known French maxim expresses the idea behind the fifth meaning rule: "En amour, on ne compte pas" (When one loves, one shouldn't count): the partner's and the couple's interests should always come first (Henchoz 2008). As one participant explained: "Obviously our partner should be the focus of our lives, our efforts, our energies. I would say that we do nothing that would be at odds with respecting the other. The partner has priority over all others" (Simon, male participant, married couple). Altruism, selflessness, and self-sacrifice are entrenched domestic and family norms; a lover or parent must act for the sake of the beloved ones, without calculating the costs (Bozon and Héran 2006; Kauffman 1993; de Singly 1996), since, in the context of love relationships, a good deed is considered rewarding in itself (Schneider 1968). Both material and immaterial generosity serves the relationship, especially in the beginning.

Partners can hardly prioritize their own financial, legal, sexual, or personal interests without contravening this meaning rule. For example, our research, as well as that of other scholars investigating financial arrangements between partners, has shown that partners seldom discuss money issues, except in the face of impending separation (Belleau et al 2017; Burgoyne and Morisson 1997; Henchoz 2008; Nyman and Evertsson 2005). Taking inspiration from Hochschild's studies of emotion work, Henchoz shows that the daily production of love can generate, maintain, or dissimulate inequalities within relationships; for instance, partners may avoid mentioning economic inequalities between them in order to strengthen the (romantic) norm of selfless giving (Henchoz 2014: 32). Additionally, this meaning rule legitimizes expectations with regard to the beloved one's behavior; we can assume that our partner will not prioritize his or her interests over our own. When one partner addresses legal or financial issues, this is often interpreted as a lack of trust, or even as a form of selfishness. One participant's comments illustrate this well. To the question, "Did you think about the legal dimension when you got married?", he responded:

Of course she does not see finances, money, possessions like me. Often in the past, it was a thing that annoyed me when ... You know she always has the habit to say: "Well, the house is half yours, half mine... that's mine...". There I said, "Look, it's up to us, you know, you have to understand that ..." She was always inclined to be a little selfish on that side, but you have to look at her previous experience. [...] For me, money is not important. Material goods are more important to her. (Marc, male participant, married couple) 
Symbolizing unity and romantic merging, this meaning rule decreases the chances that partners will plan legal and financial arrangements in the event of a break-up, since planning entails an explicit discussion in which their interests are opposed.

\section{Delayed reciprocity}

Kellerhals et al. (2004) argue that delayed reciprocity is a way for partners to reconcile the criterion of merit (calculating a fair distribution of resources and responsibilities) with that of selfless giving (love without counting); partners take for granted that what they give today will eventually be reciprocated. In contemporary love semantics, delayed reciprocity refers to both the notion of exchange and the duration of an intimate relationship. This exchange is based on the equality of the partners and a system of culturally-defined equivalences (Henchoz 2008). At least three elements carry weight in a household's balance of equivalences: the time and energy devoted to the well-being of the family; the financial contribution of each partner; and the caretaking tasks performed in domestic work and child-raising. It is entirely possible for one partner to contribute more time or money than the other without destabilizing the general balance. One participant expressed this idea with a nice metaphor:

When it's raining, it's not always the same partner who has to hold the umbrella. It's like that. At a given moment it rains in your partner's house, you take your umbrella, you hold it for your partner... If it rains at your place, your partner will hold it for you. If it rains in both places, well, both will hold the umbrella [laughs]. (Eric, male participant, de facto union)

The balance of the exchange is assessed over a long period. More than half of our participants described managing money through pooling their incomes to support one another as they experienced income fluctuations. However, these arrangements of reciprocity are not necessarily the product of explicit agreements. To avoid tensions and arguments, some couple indefinitely delay any discussion regarding the fairness of their practical arrangements. In this case, the relationship persists, but imbalances and inequalities remain concealed, further discouraging any open discussion between partners. According to our results, these inequalities and imbalances are usually gendered; while men invest more in terms of money, women contribute more in terms of time and energy, and the consequences of these imbalances are more harmful for women than for men in the long run. 
Delayed reciprocity is based on the fiction of duration, which suggests that a relationship will last long enough for reciprocation or compensation to eventually occur. When asked about what a love relationship is, one participant evokes several symbols of love, such as ongoing investment, altruism, and reciprocity:

It is to accompany a person where she is and in her good and bad times. And it is to be present. I think... it's support... it's being there when the other person needs you. I think you cannot always give without ever receiving. It's clear, it has to be reciprocal. (Justine, female participant, married couple)

When a separation occurs, all the previously concealed imbalances resurface. Delayed reciprocity, as a meaning rule, becomes obsolete and the failure of its fulfillment becomes conspicuous. At this point, each partner is in a position to recognize that reciprocation and compensation of persisting inequalities (whether financial, domestic, or otherwise) has not happened and never will. Delayed reciprocity also relies on the rule of mutual trust.

\section{Trust as foundation of a relationship}

As the role played by marriage in stabilizing intimate relationships declines, emphasis has shifted towards the relational dimension of partners' commitment (Bozon 2016; Kirkby 2008). Conjugal relationships increasingly rely on the moral power of mutual trust rather than on legally or religiously sanctified agreements. The additional emphasis placed on trust also highlights the self-referentiality of romantic love, where love provides its own foundation and justification (Luhmann 1982). In other words, conjugal relationships are increasingly grounded in the power of love rather than being secured by institutions and social norms. This meaning rule rejects the logics of law at work in the written word and the negotiated agreement, which are seen as being at odds with the involuntary, self-sufficient nature of the love relationship (Bergström 2013).

Because of its capacity to establish and maintain connections even in the face of uncertainty and incomplete information, trust is an irreplaceable support for social relationships. Trust is a cognitive shortcut that makes it possible to forego cyclic calculation and verification in making day-to-day decisions (Luhmann 1968; Van de Rijt and Busken 2006; Watier 1996). When considered in this broader context, trust can be very rational, deepening with time in concrete relationships.

Paradoxically, however, the growing importance of trust in contemporary love experience may have the effect of weakening unions. Much 
like the other meaning rules discussed above, trust can be an obstacle to explicit negotiation between partners. The injunction to trust reinforces the meaning rules of selfless giving and loving without counting; sometimes as many as ten years of conjugal life must elapse before it becomes possible to contravene these rules in order to discuss personal interests. Hence, in newer relationships, the desire of one partner to get married or to sign an agreement may be perceived by the other as indicating a lack of trust. Some believe that to "take as many precautions [for drafting a common-law agreement] can mean that one may anticipate that it will not work" (Marie-Andrée, female participant, de facto union).

Because they prefer to avoid addressing the possibility of a break-up, most couples do not like talking about money or contracts in order not to weaken their mutual trust. The example of Louis and Isabelle, far from unique, is eloquent. When buying their house, the couple received a sum of money from Isabelle's mother for the down payment required by the bank. Louis believes that his de facto partner had "enough confidence" in their relationship, "not to sign ... a paper "indicating where the down payment came from when buying their home," despite the insistence of his mother-in-law. In the latter case, it can also be assumed that coowning a house will likely strengthen trust between spouses. Indeed, this shared economic security has in return the effect of reinforcing the idea that spouses have all the reasons to trust each other.

\section{Fidelity and exclusivity}

Despite transformations in attitudes regarding conjugal relationships (Treas et al. 2014) and the increasing tendency to view sexuality as a physiological need (Genard 2005), fidelity and exclusivity continue to form the two sides of a fundamental meaning rule of contemporary love (Blais et al., 2014, Graber et al., 1999, Previti and Amato 2004), especially for heterosexual couples (Green and Valleriani 2016). While couples often simply equate fidelity with sexual exclusivity, its scope may widen to encompass both moral and sexual loyalty, which form a continuum (Bawin-Legros 2004, Blow and Hartnett 2005, Frank and DeLamater 2010). In this way, the rule of fidelity and the rule of trust support each other in contemporary love semantics.

The monogamous norm characterizing the romantic tradition extends far beyond the institutional or religious framework of marriage. The symbolic importance of the norm of exclusivity is great even where relationship boundaries are not yet clearly defined, when the relationship does not have a strong institutional structure (marriage) or even a 
material one (cohabitation, sharing of the home [Carter et al . 2016]). During our interviews, several partners more or less explicitly outlined their definition of loyalty and how they respect their conjugal agreement. Most identified marital fidelity with respect, authenticity and, above all, trust; being disloyal to one's partner was viewed as a breach of trust that could fatally endanger the relationship. For Etienne, "this is significant because we thought it was an exclusive relationship. So if loyalty was not there, the relationship would not last" (Etienne, male participant, de facto union).

\section{Conclusions}

Based on our results, we have identified eight meaning rules which are employed by actors to face the challenges of contemporary intimate relationships. In this final section, we will discuss the "logics" of couples and the "logics" of the contemporary sociological literature on intimacy more generally.

As mentioned in the introduction, the Quebec heterosexual couples whom we met operated by combining semantic elements stemming from cognitive and practical relationship patterns that sometimes diverged; meaning rules encouraging mythical idealization through images of destiny and romantic merging were combined with meaning rules hinging on ideas such as relationships as work, relationships as therapeutic communication, and entrepreneurial relationship maintenance. However, this second set of meaning rules do not necessarily encourage a cold, calculative, or realistic attitude; the introduction of these rules simply encouraged the development of a less traditional idealization style in which traditional semantic elements were reinterpreted and combined with the partnership pattern. Different idealization styles for love (such as destiny, work, selfless giving, etc.) are integrated (Piazzesi et al. 2018) and jointly contribute to stabilizing the couple, in addition to relegating "social facts" such as the increasing divorce and separation rate, serial monogamy, and gender inequalities in the division of labor and in the consequences of break-ups to a blind spot.

In our investigation of financial arrangements in heterosexual couples, the reluctance of participants to discuss money or contracts between partners made it possible to identify the boundaries separating love from the logics of the market, but also to observe the intertwining of these two "worlds" (Belleau, 2011). Money supports intimate relationships (through presents, economic support, etc.) and 
vice versa, but the meaning rules of love can conceal inequalities and power relationships within couples. Consciously or unconsciously, couples tend to overlook subjects that threaten to create tensions and conflicts in a strategic effort to maintain a harmonious relationship. This "good understanding" of lovers is often based on a fictitious consensus, which is taken for granted by the partners until a reality-check reveals its ephemeral nature (Hahn 1991).

It is also remarkable that the logics of the dissolubility of the "pure relationship" (Giddens 1992) does not appear to have altered the practices of heterosexual couples, which continue to maintain a nonrealistic attitude with regard to both the finiteness of the relationship and to the voluntary, deliberate, and negotiated nature of a break-up. As our analyses have shown, the meaning rules of love discourage partners from anticipating (not to mention planning) a break-up.

This brings us to the second type of "logics"; we have observed that contemporary literature on love and couples features a double confusion. Firstly, several theorists attempt to describe the mainstream love imaginary (autonomy, authenticity, "purity" of bonds, etc.) without investigating the degree of correspondence between this imaginary and the ideas and logics shaping couples' actual behaviors and practices (Jamieson 1999, Piazzesi 2014). As we have shown, the meaning rules employed by contemporary couples remain deeply rooted in the traditional romantic paradigm, which has not been abandoned, but instead reinterpreted to better address the stakes and challenges of contemporary society. The second confusion mirrors the first. In taking their cue from theories of modernization, many family specialists in the fields of law, economics and other disciplines appear to ignore love semantics when approaching conjugal relations. In these modernist portraits, partners are depicted as autonomous, independent, free-willed individuals, negotiating agreements on the basis of a market-like rationality. Despite its significant influence on concrete practices, emotional interdependence seldom receives adequate consideration in these accounts (Blais et al 2014, Génard 1995). As we have shown, love semantics shape romantic partners' practices, expectations, and conceptions of intimate relationships in very concrete ways.

Research on couples' practices that separates the logics of love from the logics of economics simply replicates the normative oppositions between the antagonistic worlds (Zelizer 1997) of love and money (personal interest, profit, calculation) that structure partners' expectations. However, as Zelizer and others have argued, these two "worlds" are deeply intertwined in the very same actions 
and discourses that aim to conceal the connections between them. This intertwinement motivates our interest in observing couples' practices through the prism of the meaning rules which jointly orient the practices and decisions of daily life in its affective and material aspects despite originating in very different logical patterns.

\section{REFERENCES}

Armor, David A. and Shelley Taylor. 1998. Situated optimism: Specific outcome expectancies and self-regulation. Experimental Social Psychology 30:309-379.

Averill, James R. and Phyllis Boothroyd. 1977. On Falling in Love in Conformance with the Romantic Ideal. Motivation and Emotion 1 (3):235-247.

Baker, Lynn A. and Robert E. Emery. 1993 When every relationship is above average: Perceptions and expectations of divorce at the time of marriage. Law and Human Behavior 17 (4):439-450.

Bauman, Zygmunt. 2004. L'amour liquide. De la fragilité des liens entre les hommes. Arles: Le Rouergue/Chambon.

Bawin-Legros, Bernadette. 2004. Intimacy and the New Sentimental Order. Current Sociology 52 (2):241-250.

Beck, Ulrich and Elizabeth Beck-Gernsheim. 1995. The Normal Chaos of Love. Cambridge, UK: Polity.

Beck, Ulrich and Elizabeth Beck-Gernsheim. 2001. Individualization. London: Sage.

Belleau, Helene. 2011. Quand l'amour et l'État rendent aveugle. Le mythe du mariage automatique. Québec : Presse de l'Université du Québec.

Belleau, Helene and Agnès Martial. 2011. Aimer et compter? Droit et pratiques des solidarités conjugales dans les nouvelles trajectoires familiales. Québec : Presses de l'Université du Québec.

Belleau, Hélène, Carmen Lavallée and Annabelle Seery. 2017. Unions et désunions conjugales au Québec, Report. Part 1 : Le couple, l'argent et le droit, Montréal, Canada : INRS Urbanisation Culture Société.

Bergström, Marie. 2013. La loi du supermarché? Sites de rencontres et représentations de l'amour. Ethnologie française 43 (3):433-442.

Blais Martin, Roxanne Hébert-Ratté, Martine Hébert et Francine Lavoie. 2014. Grammaire de l'expérience romantique adolescente au Québec : une analyse sociosémantique des idéaux amoureux. Sociologie et Sociétés 46 (1):203-223. 
Blow Adrian J. and Kelley Hartnett. 2005. Infidelity in Committed Relationships II: A Substantive Review. Journal of Marital and Family Therapy 31 (2):217-233.

Bowman, Cynthia G. 2010. Unmarried Couples, Law, and Public Policy. New York: Oxford University Press.

Bozon, Michel. 2016. Pratiques de l'amour. Paris: Payot.

Bozon, Michel et François Héran. 1987. La découverte du conjoint. I. Évolution et morphologie des scènes de rencontre. Population 42 (6):943-985.

Burgoyne, Carole B. and Victoria Morison. 1997. Money in remarriage: keeping things simple - and separate. The Sociological Review 45 (3):363-395.

Cancian, Francesca. 2001. [1987] Love in America. Gender and Self-development. Cambridge: Cambridge University Press.

Carter, Julia, Simon Duncan, Mariya Stoilova and Miranda Phillips. 2016. Sex, love and security: Accounts of distance and commitment in living apart together relationships. Sociology 50 (3):576-593.

Chaumier, Serge. 1999. La déliaison amoureuse: De la fusion romantique au désir d'indépendance. Paris: Armand Colin.

Cherlin, Andrew J. 2004. The deinstitutionalization of American Marriage. Journal of Marriage and Family 66 (4):848-861.

Coontz, Stephanie. 2016. Gender Equality and Economic Inequality: Impact on Marriage. In McHale, S.M. et al. (ed.), Gender and Couple Relationships. Cham, Springer: 79-90.

Coontz, Stephanie. 2005. Marriage, a History. How Love Conquered Marriage. New York: Penguin Books.

de Rougemont, Denis. 1972. [1939] L'amour et l'Occident. Paris: Plon.

de Singly, François. 1996. Le Soi, le couple et la famille, Paris: Éditions Nathan.

Dowd, James J. and Nicole R. Pallotta. 2000. The end of romance: The demystification of love in the postmodern age. Sociological Perspectives 43 (4): 549-580.

Evans, Mary. 2003. Love: An Unromantic Discussion. Cambridge (UK): Polity Press.

Frank, Katherine and John DeLamater. 2010. Deconstructing monogamy: Boundaries, identities, and fluidities across relationships. Understanding Non-Monogamies, edited by M. Barker and D. Langdridge, 9-22. New York: Routledge.

Genard, Jean-Louis. 1995. Réciprocité, sexe, passion : les trois modalités de l'amour. Sociologie de l'Amour, édité par M. Moulin et A. Eraly, 55-77. Bruxelles: Éditions de l'Université de Bruxelles.

Giddens, Anthony. 1992. The Transformation of Intimacy. Sexuality, Love and Eroticism in Modern Societies. Cambridge: Polity Press. 
Gigerenzer, Gerd. 1991. How to make cognitive illusions disappear: Beyond heuristics and biases. European Review of Social Psychology 2 (1):83115.

Girard, Chantal, Frédéric F. Payeur, Anne Binette-Charbonneau, Martine StAmour, Philippe Pacaut and Dominique André. 2013. Le bilan démographique du Québec. Édition 2013. Report. Québec: Institut de la statistique du Québec, Québec.

Girard, Chantal, Martine St-Amour, Frédéric F. Payeur, Jean-François Lachance and Dominique André. 2012. Le bilan démographique du Québec. Édition 2012. Report. Québec: Institut de la statistique du Québec, Québec.

Giraud, Christophe. 2017. L'amour réaliste - La nouvelle expérience amoureuse des jeunes femmes. Malakoff: Armand Colin.

Graber, Julia A., Pia R. Britto and Jeanne Brooks-Gunn. 1999. What's love got to do with It? Adolescents' and young adults' beliefs about sexual and romantic relationships. The Development of Romantic Relationships in Adolescence, edited by W. Furman, B. B. Brown and C. Feiring, 364395. Cambridge: Cambridge University Press.

Green, Adam I., Jenna Valleriani and Barry Adam. 2016. Marital monogamy as ideal and practice: The Detraditionalization Thesis in Contemporary Marriages. Journal of Marriage and Family (78) 2:416-430.

Gross, Neil. 2005. The detraditionalization of intimacy reconsidered. Sociological Theory 23 (3):286-311.

Hahn, A. 1991. L'entente comme stratégie. Langage et Travail 2: 19-26.

Henchoz, Caroline. 2008. Le couple et l'argent : Quand l'amour produit et reproduit des rapports de pouvoir et d'inégalités. L'usage de l'argent dans le couple: pratiques et perceptions des comptes amoureux. Perspective internationale, édité par H. Belleau et C. Henchoz, 31-74. Paris: Harmattan.

Henchoz, Caroline. 2014. La production quotidienne de l'amour en Suisse et au Québec : comptabilités intimes. Sociologie et Sociétés 46 (1):17-36.

Hefner, Veronica and Barbara J. Wilson. 2013. From love at first sight to soul mate: The Influence of romantic ideals in popular films on young people's beliefs about relationships. Communication Monographs 80 (2):150-175.

Higgins, N. C., Michelle D. St Amand and Gary D. Poole. 1997. The controllability of negative life experiences mediates unrealistic optimism. Social Indicators Research 42 (3):299-323.

Hillenkamp, Sven. 2009. Das Ende der Liebe. Gefühle im Zeitalter unendlicher Freiheit. Stuttgart: Klett-Cotta.

Illouz, Eva. 1997. Consuming the Romantic Utopia. Berkeley: University of California Press.

Illouz, Eva. 2012. Why Love Hurts. A Sociological Explanation. Cambridge: Polity Press. 
Jackson, Stevi. 2014. Love, social change, and everyday heterosexuality. Love: A Question for Feminism in the $21^{\text {st }}$ Century, edited by A. G. Jonasdottir and A. Ferguson, 33-47. London: Routledge.

Jackson, Stevi. 2003. Even sociologists fall in love. Sociology 27 (2): 201-220.

Jamieson, Lynn. 1999. Intimacy transformed? A Critical look at the 'pure relationship'. Sociology 33(3): 477-494.

Jamieson, Lynn, Michael Anderson, David McCrone, Frank Bechhofer, Robert Stewart and Yaojun Li. 2002. Cohabitation and commitment: partnership plans of young men and women, The Sociological Review 50 (3): 356377.

Jonas, Irène. 2007. 'Psy', 'coach' et travail d'amour dans l'entreprise couple': les femmes en première ligne". Famille et rapports de sexe, édité par M.B. Tahon, 141-157. Montréal: Les éditions du remue-ménage.

Kauffman, Jean-Claude. 2002. Premier matin: comment naît une histoire d'amour. Paris: Colin.

Kauffman, Jean-Claude. 2003. [1993] Sociologie du couple. Paris: PUF.

Kellerhals, Jean, Éric Widmer E and René Levy. 2004. Mesure et démesure du couple. Cohésion, crises et résilience dans la vie des couples. Paris: Payot.

Kirkby, Emma. 2008. Coexisting detraditionalization and retraditionalization in young middle class women's marriage attitudes. Paper submitted for refereed section TASA conference, Melbourne, December 2008. http:// hdl.handle.net/1959.13/45217 (consulted December 2017)

Kruithof, C. L. 1979. L'amour comme phénomène social. Bruxelles: Éditions de l'Université de Bruxelles.

Lemieux, Denise. 2003. La formation du couple racontée en duo. Sociologie et Sociétés 35 (2):59-77.

Leupold, Andrea. 1983. Liebe und Partnerschaft: Formen der Codierung von Ehen. Zeitschrift für Soziologie 12 (4):297-327.

Luhmann, Niklas. 1968. Vertrauen. Stuttgart: Enke; tr. fr. La confiance, Paris: Economica 2006.

Luhmann, Niklas. 1982. Liebe als Passion. Frankfurt am Main: Suhrkamp; tr. fr. Amour comme passion. De la codification de l'intimité. Paris: Aubier 1990.

Luhmann, Niklas. 1993. Gesellschaftsstruktur und Semantik, vol. 3. Frankfurt am Main: Suhrkamp.

Luhmann, Niklas. 1997. Die Gesellschaft der Gesellschaft. Frankfurt am Main: Suhrkamp.

Mahlmann, Regina. 1991. Psychologisierung des "Alltagsbewußtseins". Die Verwissenschaftlicung des Diskurses über Ehe. Opladen: Westdeutscher Verlag. 
Maillochon, Florence. 2016. La passion du mariage. Paris: PUF.

Martin, Claude. 2003. Les solidarités familiales : bon ou mauvais objet sociologique. Les solidarités familiales en question, édité par D. Debordeaux et P.Strobel P, 41-71. Paris: L.G.D.J.

Milan, Anne, Mireille Vézina and Carrie Wells. 2007. Portrait de famille : continuité et changement dans les familles et les ménages du Canada en 2006, Recensement de 2006. Report. Septembre. Ottawa : Statistique Canada, Ottawa.

Musiał, Maciej. 2013. Intimacy and modernity. Modernization of love in the western culture. Studia Europaea Gnesnensia 0 (7):157-168.

Nyman, Charlott. 1999. Gender equality in the most equal country in the world? Money and marriage in Sweden, The Sociological Review (47): 766-793.

Nyman, Charlott and Lars Evertsson. 2005. Difficultés liées à la négociation dans la recherche sur la famille: un regard sur l'organisation financière des couples suédois. Enfances Familles Générations (2):18-38.

Pahl, Jan. 2005. Individualisation et modèles de gestion des finances au sein des familles, Enfances, Familles, Générations (2) : 1-17.

Piazzesi, Chiara (2014). Tout sauf l'« amour » ou porter un regard sociologique sur l>intimité amoureuse. Sociologie et sociétés, 46, 1: 5-14.

Piazzesi, Chiara and Martin Blais, Julie Lavigne, Catherine Lavoie Mongrain, Roxane Renière (2018). Représentations de l'intimité et transformations sociales : vers une sémantique amoureuse intégrée. Sociologies et sociétés, 50, 2: 219-244.

Popenoe, David and Barbara D. Whitehead. 2001. The state or our union. The social health of marriage in America. Report. Piscataway: Rutgers, The State University of New Jersey.

Previti, Denise and Paul R. Amato. 2004 Is infidelity a cause or a consequence of poor marital quality?. Journal of Social and Personal Relationships $21(2): 217-230$.

Rachlinski, Jeffrey J. 2003. The uncertain psychological case for paternalism. Northewestern University Law Review 97 (3):1165-1225.

Raghu, Jyoti. 2015. True love's kiss and happily ever after: the religion of love in American film", Journal of Popular Romance Studies. http://jprstudies. org/2015/08/true-loves-kiss-and-happily-ever-after-the-religion-of-lovein-american-filmby-jyoti-raghu/ (consulté le 25 avril 2017)

Reece, Helen. 2015. Leaping without looking. After Legal Equality. Family, Sex, Kinship, edited by R. Leckey, 115-133. Abingdon: Routhledge.

Reinhardt-Becker, Elke. 2015. Romantik und kein Ende? Liebessemantiken in US-amerikanischen Fernsehserien. Sprachen der Liebe in Literatur, Film 
und Musik, edited by F. Smerilli and C. Hamann, 315-346. Würzburg: Königshausen \& Neumann.

Roussel, Louis. 1989. La famille incertaine. Paris: Éditions Odile Jacob.

Schneider, David. 1968. American Kinship. A Cultural Account. Chicago: University of Chicago Press.

Schurmans, Marie-Noël and Loraine Dominicé. 1997. Le coup de foudre amoureux : essai de sociologie compréhensive. Paris: Presses Universitaires de France.

Sharot, Tali. 2012. The Optimism Bias: Why We're Wired to Look on the Bright Side. London: Constable and Robinson.

Simon, William and John H. Gagnon. 2002. Sexual scripts: Origins, influences and changes. Qualitative Sociology (26):491-497.

Statistique Canada. 2017. État matrimonial et situation sexe opposé/même sexe selon le sexe pour les personnes âgées de 15 ans et plus vivant dans les ménages privés pour les deux sexes, total, présence et âge des enfants, chiffres de 2016, Canada, provinces et territoires, Recensement de 2016 - Données intégrales. http://www12.statcan.gc.ca/census-recensement $/ 2016 / \mathrm{dp}-\mathrm{pd} / \mathrm{hlt}$-fst $/$ fam/Tableau.cfm?Lang=F \&T $=11 \&$ $\mathrm{Geo}=00 \& \mathrm{SP}=1 \&$ view $=1 \&$ sex $=1 \&$ presence $=1 \& \mathrm{SO}=14 \mathrm{D}$ (Accessed on 5 October 2017)

Swidler, Ann. 2001. Talk of Love. How Culture Matters. Chicago - London: University of Chicago Press.

Tabet, Paola. 2004. La grande arnaque. Sexualité des femmes et échange économico-sexuel. Paris: l'Harmattan.

Théry, Irène. 1993. Le démariage. Paris: Éditions Odile Jacob.

Treas, Judith, Jonathan Lui et Zoya Gubernaskaya. 2014. Attitudes on marriage and new relationships: Cross-national evidence on the deinstitutionalization of marriage. Demographic Research 30:1495-1526.

Tyrell, Hartmann. 1987. Romantische Liebe - Überlegungen über ihre quantitative Bestimmtheit. Theorie als Passion. Niklas Luhmann zum $60 \mathrm{Ge}$ burtstag, edited by D. Baecker, J. Markowitz, R. Stichweh, H. Tyrell and H. Willke, 570-599. Frankfurt:a.M., Suhrkamp.

Van de Rijt, Arnout and Vincent Buskens. 2006. Trust in intimate relationships. The increased importance of embeddedness for marriage in the United States. Rationality and Society 18 (2):123-156.

van Hooff, Jenny. 2013. Modern Couples. Continuity and Change in Heterosexual Relationships. Farnham (UK) - Burlington (VT): Ashgate.

Villeneuve-Gokalp, Catherine. 1990. Du mariage aux unions sans papier : histoire récente des transformations conjugales. Population 45 (2):265-297.

Voléry, Ingrid. 2011. Le “couple relationel” à l'épreuve des partages financiers : séparation conjugale, entretien de l'enfant et inégalités sexuées. Aimer 
et compter? Droits et pratiques des solidarités conjugales dans les nouvelles trajectoires familiales, édité par H. Belleau et A. Martial, 203-223. Québec: Presses de l'Université du Québec.

Watier, Patrick. 1996. La confiance réciproque. Tout négocier - masques et vertiges des compromis, édité par H.-P. Jeudy, 87-93. Paris: Autrement.

Williams, Sean H. 2009. Sticky Expectations: Responses to Persistent OverOptimism in Marriage, Employment Contracts, and Credit Card Use. Notre Dame Law Review 84 (2):733-791.

Zelizer, Viviana. 1997. The Social Meaning of Money. Pin Money, Paychecks, Poor Relief, and Other Currencies. Princeton: Princeton Paperbacks.

Hélène Belleau is Full professor at Institut National de la Recherche Scientifique (INRS) and director of the Center Urbanization, Culture and Society. For several years, her research has focused on conjugal relations, the social use of money and the legal framework of de facto unions. Among her most recent books: Amour et argent : Guide de survie en 60 questions with Delphine Lobet, RemueMénage, 2017 and Quand l'amour et l'État rendent aveugle. Le mythe du mariage automatique. Presses de l’Université du Québec, Québec, 2011.

Email: $\underline{\text { Helene.Belleau@ucs.inrs.ca }}$

Chiara Piazzesi is Associate professor of sociology at the Université du Québec à Montréal. Her current research projects focus on contemporary forms of intimate relationships and on social media and digital sociability. Among her most recent publications: Grammatiche dell'amore. Studi sociologici sulle relazioni intime [Grammars of Love. Sociological Studies on Intimate Relationships], Milan, Franco Angeli 2019; Vers une sociologie de l'intime [Towards a Sociology of Intimacy], Paris, Hermann 2017.

Email: piazzesi.chiara@uqam.ca

Annabelle Seery holds a PhD in sociology from Université de Montréal. Her work is centered on Quebec heterosexual couples' arrangements by focusing on low-income parent's division of labor and money management. Her research approach is at the intersection of three fields: money, work and love. 